\title{
Where Were European Higher Education Institutions within Erasmus Mundus Action2 Strand 1?
}

\author{
Mariano Martin Perez, (PhD Candidate) \\ Jagiellonian University in Krakow, Poland
}

Doi: 10.19044/esj.2018.v14n13p51 URL:http://dx.doi.org/10.19044/esj.2018.v14n13p51

\begin{abstract}
Teichler (2009) wrote "ERASMUS was a trigger for a qualitative leap of internationalisation strategies and policies since the 1990s: towards cooperation and mobility on equal terms, and towards systematic and strategic internationalisation". Though, one might say, Higher Education Institutions (HEIs) follow that path with the aim of generating, strengthening and promoting said qualitative leap including within their institutional structures. The European Union struggled for each and every one of the HEIs to be strengthened by means of a program that allowed them to strengthen their internationalization process and give them an equality of conditions, at an EU level, as receptors of help to participate in international activities. In this sense, this study will provide an unconventional understanding of the EU's HEIs' participation level, and will try to open a debate to discuss at further depth as to how much they were able to be equal beneficiaries of the Erasmus Mundus Action 2 Strand 1. This research is part of a doctoral investigation project. It was structured as a descriptive study and it utilized secondary information which came from data published by the EACEA on its website as well as from different online documents. According to the study's findings, the EMA2S1 was an open tool for all European HEIs, but it benefitted only some of them.
\end{abstract}

Keywords: Internationalization, European Higher Education Institutions, Erasmus Mundus

\section{Introduction}

In 2003, the Official Journal announced the "establishment of a program for improving the quality of higher education and the promotion of intercultural understanding through the cooperation with third countries" (European Parliament and the Council of the European Union, 2003). The Parliament's and Council's main objective was defined as the improvement of higher education quality within the European Union. Nevertheless, in 2010, 
the Council defined "internationalization as the development of international cooperation activities between EU higher education institutions and those in third countries" (Council conclusions, 2010), thus making a clear statement of its interests for Europe.

\section{Comprehensive internationalization in the EU, just a claim}

The cluster of 3,012 Higher Education Institutions (HEIs) tagged with the Erasmus University Charter (EUC) for 2013 is part of the results of the European Community Action Scheme for the Mobility of University Students (ERASMUS), which was born in 1987. The fostering of European cooperation through its HEIs was, as it is today, a powerful tool made to provide and generate an international quality reference forum for students, teachers and researchers within the community. This was initially made for the European Community's benefit; but at the end it became intended for the rest of the world as well.

However, the number of HEIs participating in the Erasmus Mundus Action 2 Strand 1 (EMA2S1) 2007-2013 part of the Education, Audiovisual and Culture Executive Agency (EACEA) was small compared to the European Erasmus experience. The capacity of participation reached up to 262 consortia according to the EACEA's figures.

Figure 1 shows the percentage of the over 3,012 HEIs allowed to participate that were involved in some EMA2S1 partnerships in European Union countries. The reference years for EU HEI data are 2007-2013.

\section{HEI Involvement on EM2-S1} 2007-2013

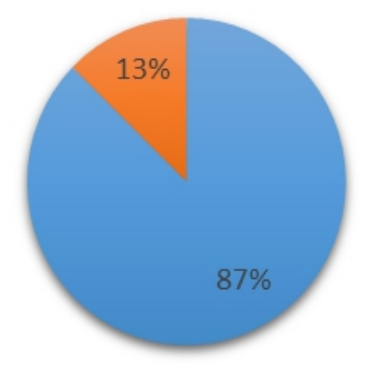

Not Involved Involved

Fig.1 Percentage of HEI involvement in EM2-S1 2007-2013

Source: own elaboration based on EACEA(2014). EU HEIs in Erasmus Mundus Action 2 Strand 1 
Against any forecast, this has become a benefit accessed by $13 \%$ of HEIs holding an EUC. ${ }^{1}$ One could say that EMA2S1 has had a low impact in shaping Europe's internationalization process. It should be noted, however, that it has accentuated the capacity and knowhow of a reduced set of HEIs to benefit from that funding.

The European internationalization process produced advantages and disadvantages. Some member states participated more in the EMA2S1, like Sweden with $32 \%$ of its total HEIs, the Netherlands with $28 \%$ and Finland and Slovakia with $24 \%$. This is in comparison with other member states like Poland with 5\%, France with 7\% and Spain with 8\% from the total of those countries which possession an Erasmus University Charter (EUC) (Figure 2). One can assert that there were winners and losers. Perhaps to make such a statement might seem like jumping to conclusions, but it is one consideration.

\begin{tabular}{|c|c|c|c|}
\hline Austria & $\mathbf{1 3 , 7 0}$ & Italy & 20,21 \\
\hline Belgium & $\mathbf{1 4 , 6 1}$ & Latvia & 18,75 \\
\hline Bulgaria & $\mathbf{1 4 , 6 3}$ & Lithuania & 8,70 \\
\hline Croatia & $\mathbf{0 , 0 O}$ & Luxembourg & 100,00 \\
\hline Cyprus & $\mathbf{1 3 , 3 3}$ & Netherlands & 28,81 \\
\hline $\begin{array}{c}\text { Czeck } \\
\text { Republic }\end{array}$ & $\mathbf{1 9 , 6 4}$ & Malta & 0,00 \\
Denmark & 3,85 & Poland & 5,86 \\
\hline Estonia & $\mathbf{2 1 , 7 4}$ & Portugal & 16,85 \\
\hline Finland & $\mathbf{2 4 , 4 9}$ & Romania & 14,06 \\
\hline France & $\mathbf{7 , 9 5}$ & Slovakia & 24,00 \\
\hline Germany & $\mathbf{1 5 , 0 7}$ & Slovenia & 8,82 \\
\hline Greece & $\mathbf{1 8 , 4 2}$ & Spain & 8,88 \\
\hline Hungary & $\mathbf{1 1 , 7 6}$ & Sweden & 32,50 \\
\hline Ireland & $\mathbf{1 3 , 5 1}$ & United & 19,41 \\
\hline
\end{tabular}

Figure 2 EU-HEI within a EUC percentage Involvement by Country ${ }^{2}$ Source: own elaboration based on EUC by country 2013.

Erasmus Mundus Action 2 Strand 1 was an instrument created to strengthen the Internationalization of European Higher Education. It was thought that it would be able to convert Europe into a higher education destination of significant international quality. Furthermore, granting the Mundus label to those HEIs best able to confirm internationalization qualities and skills was thought to be advantageous.

Sometimes as partners, but usually specifically as coordinators, these should be considered as results that weren't promoted but acquired by "prestigious" HEIs.

\footnotetext{
${ }^{1}$ It is worth noting that Croatia incorporated its institutions into the EUC in 2009/2010; that is why it is not being covered by this analysis.

${ }^{2}$ Until the Academic year 2009/2010 when Croatia was part of it with 11 HEI.-
} 


\begin{tabular}{|c|c|c|c|}
\hline Country & HEI & No of Projects Coordinated $^{\text {Average over 262 }}$ & $\begin{array}{c}\text { Aves1 Consortia } \\
\text { EMA2S }\end{array}$ \\
\hline Sweden & Lund University & 13 & $4,96 \%$ \\
\hline Belgium & University of Ghent & 11 & $4,19 \%$ \\
\hline Italy & $\begin{array}{c}\text { Polytechnic University } \\
\text { of Turin }\end{array}$ & 9 & $3,43 \%$ \\
\hline
\end{tabular}

Figure 3. HEIs Coordinating EMA2S1 projects 2007-2013

Source: own elaboration based on on EACEA(2014). EU HEIs in Erasmus Mundus Action 2 Strand 1

The ones selected as coordinators were Lund University, the University of Ghent and the Polytechnic University of Turin. Meanwhile, the leading EU partners were the University of Bologna, the University of Deusto, the University of Granada and Masaryk University.

\begin{tabular}{|c|c|c|c|}
\hline Country & HEI & $\begin{array}{c}\mathrm{N}^{\circ} \text { of Projects as } \\
\text { a Partner }\end{array}$ & $\begin{array}{c}\text { Average over 262 EMA2S1 } \\
\text { Consortia }\end{array}$ \\
\hline Italy & $\begin{array}{c}\text { University of } \\
\text { Bologna }\end{array}$ & 46 & $17,55 \%$ \\
\hline Spain & University of Deusto & 41 & $15,64 \%$ \\
\hline Spain & $\begin{array}{c}\text { University of } \\
\text { Granada }\end{array}$ & 38 & $14,50 \%$ \\
\hline Czech Republic & Masaryk University & 38 & $14,50 \%$ \\
\hline
\end{tabular}

Figure 4. HEIs winners as a partner on EMA2S1 projects 2007-2013

Source: own elaboration based on on EACEA(2014). EU HEIs in Erasmus Mundus Action 2

\section{Strand 1}

As one can see in Figure 4, there were HEIs that obtained level a larger participation rank at an individual than entire member states during the observed 2007-2013 period, i.e. Bulgaria 26, (Croatia 6), Cyprus 4, Denmark 12, Estonia 17, Finland 33, Greece 30, Hungary 12, Ireland 23, Latvia 22, Lithuania 34, Luxembourg 3, Romania 25, Slovakia 11 and Slovenia 24.

Carefully analyzing the narrow cluster of participating HEIs in the group specified above, we observed that some countries have had a high concentration rate of participation as Coordinating Institutions versus the national number of institutions participating as partners e.g. Denmark and Slovenia with 66\%, Cyprus with 50\% and Romania, Belgium, the Netherlands and Greece with over $40 \%$. On the other hand, other member states which had a better internal distribution in coordinating EMA2 with less relevant percentages were Finland with 8\%, the United Kingdom, Italy, Germany and the Czech Republic with percentages between $15 \%$ and $18 \%$.

In other words, were the existing differences between the group of HEIs from non-member countries which could potentially have benefited from Erasmus Mundus made visible or were the winning HEIs in this process simply affirmed? 
While in 2013 the Commission described EMA2S1 as a unified cooperative comprehensive instrument made to strengthen European Higher Education Institutions, one can currently observe how far it was from what occurred in reality and on the ground.

Considerable differences in the ability to coordinate EMA2S1 proposals were detected. European participation favored only certain institutions from just a few community members. Why should Erasmus+ be considered capable of reducing this difference and not increasing it?

Despite the pre-existing equality for European HEIs, did the EACEA not use necessary mechanisms, instead triggering a visible difference in the number and profile of coordinating institutions and/or partners in EMA2? A potential difference determines various and distinct levels of internationalization in Europe's 28 member states.

Rudzik (1998, pp. 220, 221) considered that "any approach to internationalization will not only be influenced by the external factors in the context, but also by internal factors", though at an institutional level one may observe that:

The approach can be understood to fall on a continuum which ranges from overt internationalization (proactive) through passive (reactive), covert and non-existent or deliberate non-engagement.

Overt approaches will be proactive and explicit, and be based on a clear strategy and policy.

Passive approaches will be reactive and will be mainly a response to external factors such as the availability of external funding or the need to increase income as a response to governmental cuts in funding.

Covert approaches are identifiable by activities being undertaken by individuals - both staff and students - operating without official support. Indeed a great deal of such covert activity may be taking place unbeknown to the institution's management, precisely because no audit has been undertaken, and because funding or other types of support are not made available.

Thus, one should analyze results at the end of the program, describing what was achieved by the EU's HEIs.

\section{Yes to EU Internationalization although not for all}

The path built in this program's seven years has been a perfect catalyst which has accentuated differences within the HEIs' internationalization. As one can see, a tag has been assigned to some of that dynamic's leaders. On the other hand, those HEIs which were well managed were dynamic enough to improve their own structure and generate strong benefits.

One can ask, however, what were the Commission's goals beyond its internationalization rhetoric? If "internationalisation describes a process in which an institution moves, in a more or less steered process" (Brandenburg, 
\& Federkeil, 2007, p. 7), the result is then the difference between the actual situation after the EMAS1 period's expiration and the desired situation after the EMA2S1 period's expiration. Have any HEIs desired any situation?

One can see a leadership which has had the goal of creating a Europe of internationalized higher educational institutions - even if only part of the process has been achieved - but which has done nothing to monitor or evaluate it in depth. Despite being described as its initial aim, the strengthening of the European Higher Education Institutions' internationalization has not been much of a success; rather quite the opposite. Looking at the updated definition from Knight (2003: p. 2) "Internationalization at the national, sector, and institutional levels is defined as the process of integrating an international, intercultural, or global dimension into the purpose, functions or delivery of postsecondary education" it is worth asking if European HEIs did this or not.

The less bulky participation of institutions that incorporated EMA2S1 as a feature into their everyday work drove institutions to the processes and results of European differences which have been observed.

Both EMECW and EMA2S1 pursued, as European programs, the promotion of international cooperation, based upon the relationship of their HEIs with third countries in an effort to internationalize themselves. In other words, each and every HEI in the EU's 27 member states were supposed to be able to formulate, coordinate and participate. Were all of Europe's HEIs ready to? Moreover, are they ready to today within the Erasmus+ scheme?

\section{Conclusion}

Observing the degree of HEIs' involvement in the process was attempted. Participation and the use of cooperation as an instrument has been uneven; a small number of participation among European HEIs which were empowered to do so was found. This suggests, indeed, that the differences between European member states have increased rather than reduced or eliminated.

Was the European strategy successful? Rhetorically, it was. Both extremes can be indicators of the need to strengthen participation instruments in the development of consortia between European and third-country HEIs. Assessments periodically made by the EACEA should consider this negative effect.

Androulla Vassiliou claimed in July of 2013 that the new strategy's aim will not be to expand Europe's position in the international landscape of education, but to maintain it (http://www.universityworldnews.com/article.php?story=201307121015223 9 ). The EACEA, together with representatives from the EU's 28 member states, should conduct a thorough analysis of the application of this tool at home. 
Yes, the European Communication of Higher Education in the World outlines priorities for institutions and countries to develop comprehensive internationalization strategies. Through HEIs, member states must first improve their strategic cooperation skills and then enlighten the process of building alliances and creating abilities for them within the European community. Though they should, however, advance to a comprehensive European internationalization process.

As Hudzik (2011, p.10) said,

Comprehensive internationalization is a commitment, confirmed through action, to infuse international and comparative perspectives throughout the teaching, research, and service missions of higher education. It shapes institutional ethos and values and touches the entire higher education enterprise. It is essential that it be embraced by institutional leadership, governance, faculty, students, and all academic service and support units. It is an institutional imperative, not just a desirable possibility. Comprehensive internationalization not only impacts all of campus life but the institution's external frames of reference, partnerships, and relations.

The Matthew Effect applied to ERASMUS Mundus should say that the creation of the European Union's internationalization is part of a reality that should be currently addressed to avoid further disputes over Erasmus+. In other words, to paraphrase Merton (1968, p. 2), the EU is peculiar in the matter of how it gives support. It tends to give opportunities to [already] strong HEIs.

\section{References:}

1. No, D. (2003). 2317/2003/EC of the European Parliament and of the Council of 5 December 2003 establishing a programme for the enhancement of quality in higher education and the promotion of intercultural understanding through cooperation with third countries (Erasmus Mundus) (2004 to 2008). Official Journal of the European Union L, 345, 1-8.

2. Council conclusions of 11 May 2010 on the internationalisation of higher education (2010/C 135/04). Official Journal of the European Union, 26.5.2010 C 135/12.

3. European higher education in the world Communication from the Commission to the European Parliament, the Council, the European Economic and Social Committee and the Committee of the regions Brussels, 11.7.2013 COM(2013) 499 final. Retrieved from: http://eurlex.europa.eu/legal-content/EN/ALL/?uri=CELEX:52013DC0499

4. Hudzik, J. K. (2011). Comprehensive internationalization: From concept to action. Retrieved from: https://www.nafsa.org/uploadedFiles/NAFSA_Home/Resource_Libra 
ry_Assets/Publications_Library/2011_Comprehen_Internationalizatio n.pdf

5. Knight, J. (2003). Updated definition of internationalization. International higher education, (33) pp.2, 3. doi: https://doi.org/10.6017/ihe.2003.33.7391

6. Merton, R. K. (1968). The Matthew effect in science: The reward and communication systems of science are considered. Science, 159(3810), 56-63.

7. Rudzki, R. E. J. (1998). Strategic management of internationalization: towards a model of theory and practice.

\section{Websites}

8. EACEA:

http://eacea.ec.europa.eu/erasmus_mundus/funding/2014/call_eacea_ 18_13_en.php

9. EU HEIs in Erasmus Mundus Action 2 Strand 1 